\title{
STRATEGI SERVICE QUALITY SEBAGAI MEDIA DALAM MENCIPTAKAN KEPUASAN DAN LOYALITAS PELANGGAN
}

\author{
Nik Haryanti \\ Institut Agama Islam Pangeran Diponegoro Nganjuk \\ nikharyanti1983@gmail.com \\ Diyanus Abdul Baqi \\ Pengawas Madrasah Kementrian Agama Kabupaten Blitar \\ abae.aqila@gmail.com
}

\begin{abstract}
Quality of service is one of the factors that determine customer satisfaction. The good quality of service and its effectiveness in carrying out the promotion mix will provide positive responses to customer satisfaction to remain loyal using its services. The creation of customer satisfaction can provide several benefits, including the relationship between the company and the customer to be harmonious, provide a good basis for repurchase and create customer loyalty and form word-of-mouth recommendations that benefit the company. This means that the existence of a good quality of service will be a driving factor for increasing consumer satisfaction so that there will be repeated consumption of products sold until consumer loyalty is created. This type of research uses library research or library research. Literature research is a study conducted in a library room to collect and analyze data sourced from libraries in the form of periodical books such as periodicals, periodicals, historical stories, documents and other library materials that are can be used as a reference source for compiling a scientific report. Data analysis techniques used content analysis. The results of this study prove that loyalty will be created by maintaining an image through creating a good perception of product attributes and implementing a service recovery program by apologizing for making mistakes, taking immediate action, showing remorse, providing guarantees and following up. Besides creating customer satisfaction is a variable that cannot be left behind in order to create a reason for customers to remain willing to establish long-term relationships with the company.
\end{abstract}

Keywords: service quality, satisfaction, loyalty

\section{Pendahuluan}

Konsep kualitas pelayanan telah menjadi faktor yang dominan terhadap keberhasilan suatu organisasi. Service quality tidak hanya diadopsi oleh lembaga penyelenggara jasa-jasa komersial, tetapi juga telah digunakan oleh lembagalembaga pemerintahan, yang selama ini resisten terhadap tuntutan kualitas pelayanan publik yang prima. Dengan demikian, kunci agar perusahan tetap eksis adalah kemampuan perusahaan untuk mempertahankan pelanggannya (retensi). 
Apabila pelanggan pergi (defeksi), maka eksistensi perusahaan tidak diperlukan lagi, dan sebaliknya. Oleh karena itu perusahaan perlu mendeteksi sikap pelanggannya. Pemahaman pemasar terhadap sikap pelanggan, dapat membantu pemasar untuk dapat mempengaruhi dan mengubah sikap konsumen ke arah yang positif.

Kualitas pelayanan menjadi salah satu faktor yang menentukan kepuasan pelanggan. Baiknya kualitas pelayanan dan efektifnya dalam melakukan bauran promosi akan memberikan respon positif terhadap kepuasan konsumen untuk tetap loyal menggunakan jasanya. Terciptanya kepuasan pelanggan dapat memberikan beberapa manfaat, diantaranya hubungan antara perusahaan dan pelanggan menjadi harmonis, memberikan dasar yang baik bagi pembelian ulang dan terciptanya loyalitas pelanggan dan membentuk rekomendasi dari mulut ke mulut (word of mouth) yang menguntungkan bagi perusahaan. Hal ini berarti bahwa eksistensi kualitas pelayanan yang baik, akan menjadi faktor pendorong untuk meningkatkan kepuasan konsumen sehingga akan terjadi konsumsi yang berulang terhadap produk yang dijual hingga terciptanya loyalitas konsumen.

Kriteria produk jasa yang berkualitas harus diukur melalui konsep kepuasan pelanggan. Hal ini karena persaingan antara penyedia layanan jasa semakin meningkat sehingga penyedia jasa harus menekankan pada kualitas jasa melalui peningkatan kualitas pelayanan. Kualitas pelayanan menekankan pada kepuasan konsumen karena karakterstik produk jasa merupakan sesuatu yang tidak berwujud dan tidak bisa disimpan sehingga produk jasa yang dijual merupakan pelayanan yang ditawarkan kepada konsumen yang mempengaruhi kepuasan dan keinginan konsumen untuk melakukan pembelian ulang produk jasa yang ditawarkan.

\section{Kajian Pustaka}

\section{A. Service Quality}

Sebuah perusahaan dapat memenangkan persaingan dengan menyampaikan secara konsisten layanan yang bermutu lebih tinggi dibandingkan para pesaing dan yang lebih tinggi dari pada harapan pelanggan. Harapan-harapan itu dibentuk oleh pengalaman di masa lalu, pembicaraan dari 
mulut ke mulut, dan iklan perusahaan jasa. Setelah menerima jasa itu, pelanggan membandingkan jasa yang dialami dengan jasa yang diharapkan. Jika jasa yang dialami berada dibawah jasa yang diharapkan, pelanggan tidak berminat lagi terhadap penyedia jasa itu. Jika jasa yang dialami memenuhi atau melebihi harapan,mereka akan menggunakan penyedia jasa itu lagi.

Goesth dan Davis yang dikutip Tjiptono, mengemukakan bahwa kualitas diartikan "sebagai suatu kondisi dinamis dimana yang berhubungan dengan produk, jasa, manusia, proses dan lingkungan yang memenuhi atau melebihi harapan."1 Kemudian Triguno juga mengungkapkan hal yang senada tentang kualitas, yang dimaksud dengan kualitas adalah, "Suatu standar yang harus dicapai oleh seseorang atau kelompok atau lembaga atau organisasi mengenai kualitas sumber daya manusia, kualitas cara kerja, proses dan hasil kerja atau produk yang berupa barang dan jasa." 2 Pengertian kualitas tersebut menunjukan bahwa kualitas itu berkaitan erat dengan pencapaian standar yang diharapkan.

Berbeda dengan Lukman yang mengartikan kualitas adalah "sebagai janji pelayanan agar yang dilayani itu merasa diuntungkan."3 Kemudian Ibrahim melihat bahwa kualitas itu "sebagai suatu strategi dasar bisnis yang menghasilkan barang dan jasa yang memenuhi kebutuhan dan kepuasan konsumen internal dan eksternal, secara eksplisit maupun implisit." ${ }^{4}$

Pengertian yang lebih rinci tentang kualitas diberikan oleh Tjiptono, setelah melakukan evaluasi dari definisi kualitas beberapa pakar, kemudian Tjiptono menarik 7 (tujuh) definisi yang sering dikemukakan terhadap konsep kualitas, definisi-definisi kualitas menurut Tjiptono tersebut, adalah sebagai berikut:

a. Kesesuaian dengan persyaratan atau tuntutan;

b. Kecocokan untuk pemakaian;

c. Perbaikan atau penyempurnaan berkelanjutan:

d. Bebas dari kerusakan atau cacat;

${ }^{1}$ Fandy Tjiptono dan Chandra Gregorius. Service Quality and Satisfaction.(Yogyakarta: Andi Offset, 2002), 51

2 Triguno, Budaya Kerja, (Jakarta : Golden Terayon Press, 1997), 76

${ }^{3}$ Sampara Lukman. Manajemen Kualitas Pelayanan, (Jakarta: STIA LAN. 2000), 11.

${ }^{4}$ Ibrahim, Prinsip-Prinsip Total Quality Service (Yogyakarta: Andi, 1997), 1 
e. Pemenuhuan kebutuhan pelanggan semenjak awal dan setiap saat;

f. Melakukan segala sesuatu secara benar semenjak awal; dan

g. Sesuatu yang bisa membahagiakan pelanggan. ${ }^{5}$

Dari pengertian tersebut tampak bahwa, disamping kualitas itu menunjuk pada pengertian pemenuhan standar atau persyaratan tertentu, kualitas juga mempunyai pengertian sebagai upaya untuk melakukan perbaikan dan penyempurnaan secara terus menerus dalam pemenuhan kebutuhan pelanggan sehingga dapat memuaskan pelanggan.

Kualitas pelayanan adalah tingkat keunggulan yang diharapkan dan pengendalian atas tingkat keunggulan tersebut untuk memenuhi keinginan pelanggan. Apabila jasa atau pelayanan yang diterima atau dirasakan (perceived service) sesuai dengan yang diharapkan, maka kualitas jasa atau pelayanan dipersepsikan baik dan memuaskan. Jika jasa atau pelayanan yang diterima melampaui harapan pelanggan, maka kualitas jasa atau pelayanan dipersepsikan sebagai kualitas yang ideal. Sebaliknya jika jasa atau pelayanan yang diterima lebih rendah daripada yang diharapkan, maka kualitas jasa atau pelayanan dipersepsikan buruk.

Kualitas pelayanan dapat diukur dengan melihat tingkat kesenjangan antara harapan atau keinginan konsumen dengan persepsi mereka terhadap kinerja produk atau perusahaan yang diterima oleh konsumen yang dapat dijelaskan dalam skala service quality (Servqual scale). Penelitian menunjukkan bahwa Servqual dapat menjadi alat yang efektif dan stabil untuk mengukur service quality melalui industri jasa. ${ }^{6}$

Menurut Tjiptono menyatakan bahwa service quality adalah pemenuhan kebutuhan dan keinginan pelanggan serta ketepatan penyampaiannya untuk mengimbangi harapan pelanggan. ${ }^{7}$ Dengan demikian, ada dua faktor utama yang mempengaruhi kualitas jasa yaitu jasa yang diharapkan (expected service) dan jasa yang dirasakan/dipersepsikan (perceived service).

\footnotetext{
${ }^{5}$ Tjiptono dan Gregorius. Service Quality ..., 2.

${ }^{6}$ A. Parasuraman Valerie Zeithaml, and L.Berry. Servqual: Multiple Item Scale for Measuring Consumer Perceptions of Service Quality, Journal of Retailing, 64 (15), 1988,12-36

${ }^{7}$ Tjiptono dan Gregorius. Service Quality ..., 52.
} 
Pasuraman menyatakan ada lima dimensi yang digunakan oleh pelanggan untuk menilai kualitas pelayanan pada suatu industri yaitu: ${ }^{8}$ Kehandalan (reliability) merupakan suatu kemampuan untuk memberikan jasa yang dijanjikan dengan akurat dan terpercaya, dimana kinerja harus sesuai dengan harapan pelanggan yaitu ketepatan waktu, pelayanan yang sama untuk semua pelanggan tanpa ada kesalahan. Ketanggapan (responsiveness) merupakan suatu kebijakan untuk membantu dan memberikan pelayanan yang cepat kepada pelanggan. Jaminan / kepastian (assurance), yaitu pengetahuan dan keramahan karyawan serta kemampuan melaksanakan tugas secara spontan, yang dapat menjamin kinerja yang baik sehingga menimbulkan kepercayaan dan keyakinan pelanggan. Empati (emphaty), yaitu memberikan perhatian yang bersifat individual atau pribadi kepada pelanggan dan berupaya untuk memahami keinginan konsumen. Berwujud (tangibles), yaitu penampilan dan kemampuan sarana dan prasarana fisik yang dapat diandalkan, serta keadaan lingkungan sekitar sebagai bukti nyata dari pelayanan yang diberikan oleh pemberi jasa.

Menurut Parasuraman et al mengungkapkan ada 22 faktor penentu service quality yang dirangkum ke dalam lima faktor dominan atau lebih dikenal dengan istilah Servqual, yaitu reliability, responsiveness, assurance, empathy, dan tangible. ${ }^{9}$

\section{Reliability}

Kemampuan untuk memberikan jasa yang dijanjikan dengan handal dan akurat. Dalam arti luas, keandalan berarti bahwa perusahaan memberikan janji-janjinya tentang penyediaan, penyelesaian masalah dan harga. Jika dilihat dalam bidang usaha jasa bioskop, maka sebuah layanan yang handal adalah ketika seorang karyawan bioskop mampu memberikan pelayanan sesuai yang dijanjikan dan membantu penyelesaian masalah yang dihadapi penonton dengan cepat.

\section{. 2. Responsiveness}

Kemauan untuk membantu pelanggan dan memberikan jasa dengan cepat. Dimensi ini menekankan pada perhatian dan ketepatan ketika

${ }^{8}$ Parasuraman et al, Servqual: Multiple Item Scale ..., 24.

${ }^{9}$ Ibid., 32. 
berurusan dengan permintaan, pertanyaan, dan keluhan pelanggan. Kemudian jika dilihat lebih mendalam pada layanan yang cepat tanggap di sebuah bioskop, bisa dilihat dari kemampuan karyawan bioskop yang cepat memberikan pelayanan kepada pengunjung/penonton dan cepat menangani keluhan mereka.

\section{Assurance}

Pengetahuan, sopan santun, dan kemampuan karyawan untuk menimbulkan keyakinan dan kepercayaan. Dimensi ini mungkin akan sangat penting pada jasa layanan yang memerlukan tingkat kepercayaan cukup tinggi. Contohnya seperti bank, asuransi, dan broker. Tentu saja dalam sebuah jasa bioskop, kepastian menjadi hal yang penting untuk dapat diberikan kepada para penontonnya seperti jaminan keamanan dan keselamatan selama menonton di dalam bioskop.

\section{Emphaty}

Kepedulian dan perhatian secara pribadi yang diberikan kepada pelanggan. Inti dari dimensi empati adalah menunjukkan kepada pelanggan melalui layanan yang diberikan bahwa pelanggan itu spesial, dan kebutuhan mereka dapat dimengerti dan dipenuhi. Dalam menjaga hubungan baik, tentu saja layanan yang diberikan oleh para karyawan harus dapat menunjukkan kepedulian mereka kepada penonton.

\section{Tangible}

Berupa penampilan fasilitas fisik, peralatan, staff, dan bangunannya. Dimensi ini menggambarkan wujud secara fisik dan layanan yang akan diterima oleh konsumen. Contohnya seperti keadaan studio bioskop, fasilitas bioskop, desain bioskop, dan kerapian penampilan karyawan.

\section{B. Kepuasan Pelanggan}

\section{Pengertian Kepuasan Pelanggan}

Kata kepuasan atau satisfaction berasal dari bahasa latin "satis" (artinya cukup baik, memadai) dan "facio" (melakukan atau membuat). Secara sederhana kepuasan dapat diartikan sebagai upaya pemenuhan sesuatu yang memadai.Dalam konsep kepuasan pelanggan, terdapat dua 
elemen yang mempengaruhinyayaitu harapan dan kinerja. Kinerja adalah persepsi konsumen terhadap apa yang diterima setelah mengkonsumsi produk. Harapan adalah perkiraan konsumententang apa yang akan diterima apabila ia mengkonsumsi produk (barang atau jasa).

Kepuasan pelanggan merupakan hal yangpenting bagi penyelenggara jasa, karena pelanggan akan menyebarluaskan rasa puasnyakepada calon pelanggan, sehingga akan menaikkan reputasi pemberi jasa. Menurut Kotler dalam Lupiyoadi "Kepuasan pelangganyaitu tingkat perasaan dimana seseorang menyatakan hasil perbandingan ataskinerja produk atau jasa yang diterima sesuai yangdiharapkan" ${ }^{10}$

Adapun menurut Kotler dan Keller kepuasan (satisfaction) adalah perasaan senang atau kecewa seseorangyang timbulkarena membandingkan kinerja yang dipersepsikan produk (atau hasil) terhadap ekspektasi mereka. Jika kinerja gagal memenuhi ekspektasi, pelanggan akan tidak puas. Jika kinerja sesuai dengan ekspektasi, pelanggan akanpuas. Jika kinerja melebihi ekspektasi, pelanggan akan sangat puas atau senang. ${ }^{11}$

Menurut Howard dan Sheth dalam Tjiptono Kepuasan pelanggan adalah situasi kognitif pembeli berkenaan dengan kesepadanan atau ketidaksepadanan antara hasil yang didapatkan dibandingkan dengan pengorbanan yang dilakukan". ${ }^{2}$

Kepuasan pelanggan adalah suatu tanggapan emosional pada evaluasi suatu pengalaman konsumsi suatu produk atau jasa. Kepuasan pelanggan merupakan evaluasi alternative yang dipilih sekurangkurangnya melampaui harapan pelanggan. Seperti yang dikemukakan Engel dkk bahwa kepuasan pelanggan adalah respon efektif terhadap pengalaman melakukan konsumsi yang spesifik atau evaluasi kesesuaian

\footnotetext{
${ }^{10}$ R. Lupiyoadi, Manajemen Pemasaran Jasa Teori dan Praktik. (Jakarta: Salemba Empat, 2006), 192.

${ }^{11}$ Philip Kotler dan Kevin Lane Keller. Manajemen Pemasaran. diterj. Bob Sabran. (Jakarta: Erlangga. 2008), 139

${ }^{12}$ Fandy Tjiptono, Manajemen Jasa. (Yogyakarta: Andi Offset. 2011), 43
} 
atau ketidaksesuaian yang dirasakan antara harapan sebelumnya dan kinerja actual produk setelah pemakaian. ${ }^{13}$

Kepuasan pelanggan dapat menjadi dasar menuju terwujudnya konsumen yang loyal atau setia. Kotler dan Amstrong mengemukakan bahwa: "Kepuasan konsumen adalah tingkat perasaan seseorang setelah membandingkan kinerja atau hasil yang dirasakan dibandingkan dengan harapan”. ${ }^{14}$ Kepuasan atau ketidakpuasan pelanggan ialah merupakan respon konsumen terhadap ketidaksesuaian atau diskonfirmasi yang dirasakan antara harapan sebelumnya dan kinerja aktual yang dirasakan pemakainya. Jadi pada dasarnya kepuasan konsumen mencakup perbedaan terhadap harapan terhadap hasil yang dirasakan oleh konsumen atau pelanggan.

Adapun mengenai kepuasan ini Cravens yang dikutip oleh Samuel dan Foedjiwati lebih mengemukakan pemuasan pelanggan harus disertai dengan pemantauan terhadap kebutuhan dan keinginan mereka. ${ }^{15}$ Kepuasan pelanggan akan dipengaruhi oleh sistem pengiriman produk, performa produk atau jasa, citra perusahaan/produk/merek, nilai harga yang dihubungkan dengan nilai yang diterima pelanggan, prestasi karyawan, keunggulan dan kelemahan pesaing.

Hal ini sesuai dengan yang dikatakan Philip Kotler yang menyatakan kunci untuk mempertahankan pelanggan adalah kepuasan pelanggan. Pelanggan yang puas akan :

1. Melakukan pembelian ulang

2. Mengatakan hal yang baik tentang perusahaan kepada orang lain (rekomendasi).

3. Kurang memperhatikan merek dan iklan produk pesaing.

\footnotetext{
${ }^{13}$ Engel. James F., Roger D. Blackwell, Paul .W Miniad. Perilaku Membeli, (Jakarta: Binarupa Aksara, 1993), 54.

${ }^{14}$ Philip Kotler dan Gary Armstrong, Prinsip-prinsip Pemasaran, Jilid 1, (Jakarta: Erlangga, 2008), 57.

${ }^{15}$ Hatane Samuel dan Foedjiawati. "Pengaruh Kepuasan Konsumen Terhadap Kesetiaan Merek (Studi Kasus Restoran The Prime Steak \& Ribs Surabaya)" Jurnal Manajemen \& Kewirausahaan Vol. 7 tahun 2003. Surabaya: UKP Surabaya. 2005.
} 
4. Membeli produk lain dari perusahaan yang sama. ${ }^{16}$

Menurut Fandy Tjiptono kepuasan pelanggan merupakan evaluasi purnabeli dimana alternatif dipilih sekurang-kurangnya memberi hasil yang sama atau melampaui harapan pelanggan, sedangkan ketidakpuasan pelanggan timbul ketika hasil (outcome) yang tidak sesuai dengan harapan. ${ }^{17}$ Seorang konsumen mungkin mengalami berbagai tingkat kepuasan yaitu bilamana kinerja produk tidak sesuai dengan harapannya setelah dikonsumsi maka konsumen itu akan merasa tidak puas sehingga dari pembelajaran tersebut konsumen akan kecewa. Namun bila terjadi sebaliknya yaitu kinerja produk sesuai dengan persepsi konsumen maka konsumen akan merasa sangat puas sehingga di waktu yang akan datang konsumen bergairah untuk mengkonsumsi produk tersebut kembali.

Perusahaan sudah selayaknya memberikan tingkat kepuasan yang tinggi terhadap para konsumennya, sebab konsumen yang mendapatkan kepuasan yang cukup hanya akan bertahan sementara waktu dan dapat mudah beralih pada perusahaan/produk sejenis yang lain yang memberikan penawaran yang lebih baik. Pelanggan yang memberikan tingkat kepuasan yang tinggi akan memiliki ikatan pada merek produk, bukan hanya preferensi rasional dan akhirnya semua ini akan membangun loyalitas pelanggan.

Pelanggan yang tidak mendapat kepuasan akan kabur bahkan tidak akan pernah kembali. Pelanggan memilih berganti produk atau merek karena hal-hal seperti: tidak puas dengan produk yang tersedia, munculnya produk lain yang lebih baik, pengaruh teman atau kerabat, pelanggan yang ingin benar-benar berpindah merek, ketidakpuasan dengan perilaku pemilik, manajer atau perilaku karyawan perusahaan. Menurut Handito satu dari lima orang mendapat cerita ketidakpuasan akan menceritakan kembali kepada dua puluh kerabat atau orang terdekat. Selanjutnya tujuh dari sepuluh orang konsumen yang keluhannya ditanggapi dan ditangani pada saat itu juga maka 95\% konsumen akan tetap loyal terhadap produk

${ }^{16}$ Kotler dan Armstrong, Prinsip-prinsip Pemasaran..., 98

17 Tjiptono, Manajemen Jasa ..., 54 
tersebut. ${ }^{18}$ Pada dasarnya tujuan dari suatu bisnis untuk menciptakan pelanggan yang merasa puas. Terciptanya kepuasan pelanggan dapat memberikan beberapa manfaat, di antaranya hubungan antara perusahaan dan pelanggannya menjadi harmonis, memberikan dasar yang baik bagi pembelian ulang, terciptanya loyalitas pelanggan terhadap suatu produk tertentu dan membentuk suatu rekomendasi dari mulut ke mulut yang menguntungkan bagi perusahaan.

Dari berbagai pengertian di atas dapat disimpulkan bahwa kepuasan pelanggan adalah hasil perbandingan atas kinerja prodk atau jasa yang dipersepsikan dari seleksi spesifik yang berkenaan dengan kesepadanan atau ketidaksepadanan yang didapatkan denganpengorbanan yang dilakukan.

\section{Komponen Kepuasan Pelanggan}

Menurut Giese \& Cole (2000), skalipun banyak definisi kepuasan pelanggan, namun secara umum tetap mengarah kepada tiga komponen utama, yaitu:

a. Respon: tipe dan identitas

Kepuasan pelanggan merupakan respon emosional dan juga kognitif. Intesitas responnya mulai dari sangat puas dan menyakiti produk sampai sikap yang apatis terhadap produk tertentu.

b. Fokus

Fokus pada performansi objek disesuaikan pada beberapa standar. Nilai standar ini secara langsung berhubungan dengan produk, komsumsi, keputusan berbelanja, penjual dan toko.

c. Waktu Respon

Respon terjadi pada waktu tertentu, antara lain: setelah konsumsi, setelah pemilihan produk atau jasa, berdasarkan pengalaman akumulatif. Durasi kepuasan kepada berapa lama respon kepuasaan itu berakhir. ${ }^{19}$

\footnotetext{
${ }^{18}$ Handito Hadi, Intisari, Jangan Sekedar Service, (Jakarta: Gramedia, 2003), 69

${ }^{19}$ Giese \& Cote Academy of Marketing Science Review. Defining Consumer Satisfaction Volume 2000 No. 1 . (2000). Available: http://www.amsreview.org/articles/giese01-2000.pdf
} 


\section{Dimensi Kepuasan Pelanggan}

Menurut Barnes ada lima dimensi kepuasan yaitu sebagai berikut: ${ }^{20}$

a. Kepuasan terhadap wujud pelayanan itu sendiri sebagai elemen yang paling mendasar.

b. Kepuasan terhadap layanan pendukung atas jasa yang ditawarkan.

c. Kepuasan terhadap konsistensi pelayanan, antara janji - janji perusahaan dengan faktanya.

d. Kepuasan terhadap elemen-elemen yang berperan dalam interaksi dengan pelanggan.

e. Kepuasan terhadap seluruh dimensi pelayanan akan menciptakan kepuasan emosional, yaitu tingkat kepuasan pelanggan yang sesungguhnya (secara umum/ojek secaraumum).

\section{Pengukuran Kepuasan Pelanggan}

Kotler, et al dalam Tjiptono mengidentifikasi empat metode untuk mengukur kepuasan pelanggan, yaitu sebagai berikut:

a. Sistem Keluhan dan Saran

Setiap organisasi yang berorientasi pada pelanggan (customeroriented) perlu memberikan kesempatan yang luas kepada para pelanggannya untuk menyampaikan saran, pendapat, dan keluhan mereka. Media yang digunakan bisa berupa kotak saran yang diletakkan di tempat-tempat strategis (yang mudah dijangkau atau dilewati pelanggan), kartu komentar (yang bisa diisi langsung maupun yang bisa dikirim melalui via pos kepada perusahaan), saluran telepon khusus bebas pulsa, dan lain-lain. Informasi-informasi yang diperoleh melalui metode ini dapat memberikan ide-ide baru dan masukanyang berharga kepada perusahaan, sehingga memungkinkan untuk bereaksi dengan tanggap dan cepat untuk mengatasi masalah-masalah yang timbul.

\footnotetext{
${ }^{20}$ Barnes G. James, Secrets of Customer Relation ship Management (Rahasia. Manajemen
} Hubungan Pelanggan). (Yogyakarta : Andi, 2000), 67-73. 


\section{b. Ghost Shopping}

Salah satu cara untuk memperoleh gambaran mengenai kepuasan pelanggan adalah dengan mempekerjakan beberapa orang (ghost shopper) untuk berperan atau bersikap sebagai pelanggan/pembeli potensial produk perusahaan dan pesaing. Kemudian mereka melaporkan temuan-temuannya mengenai kekuatan dan kelemahan produk perusahaan dan pesaing berdasarkan pengalaman mereka dalam pembelian produk-produk tersebut.

c. Lost Customer Analysis

Perusahaan seyogyanya menghubungi para pelanggan yang telah berhenti membeli atau yang telah pindah memasok agar dapat memahami mengapa hal ini terjadi dan supaya dapat mengambil kebijakan perbaikan/penyempurnaan selanjutnya.

d. Survei kepuasan pelanggan

Umumnya banyak penelitian mengenai kepuasan pelanggan yang dilakukan dengan penelitian survai, baik melalui survei pos, telepon, maupun wawancara pribadi. Melalui survei perusahaan akan memperoleh tanggapan dan umpanbalik secara langsung dari pelanggan dan juga memberikan tanda positif bahwa perusahaan menaruh perhatian terhadap para pelanggannya. ${ }^{21}$

\section{Loyalitas Pelanggan}

Loyalitas adalah suatu komitmen yang mendalam untuk membeli kembali atau berlangganan suatu produk dan jasa secara konsisten dimasa yang akan datang sehingga dapat menyebabkan penggulangan pembelian merek yang sama walaupun ada pengaruh situasi dan berbagai usaha pemasaran yang berpotensi untuk menyebabkan tindakan perpindahan merek. $^{22}$

Loyalitas pelanggan merupakan hal yang sangat penting bagi kelangsungan suatu usaha. Karena loyalitas pelanggan dapat membentuk

\footnotetext{
${ }^{21}$ Tjiptono, Manajemen Jasa ..., 34.

${ }^{22}$ Oliver, Richard L dan Jhon E Swan, Consumer Perceptions of Interpersonal Equity and Satisfaction in Transaction: a Field Survey Approach, Journal Marketing, 1993, 34.
} 
pasar yang merupakan salah satu sumber bagi perusahaan untuk memasarkan produknya.

Dengan terciptanya loyalitas pelanggan terhadap suatu usaha, akan memudahkan perusahaan untuk menjaga kontinuitas usahanya. Loyalitas pelanggan mempunyai karakteristik, sesuai dengan tingkatan loyalitas itu sendiri. Karakteristik inilah yang menjadi tolak ukur, sejauh mana loyalitas pelanggan yang ada di perusahaan, sehingga perusahaan dapat menentukan kebijakan berdasarkan karakteristik tersebut. Menurut Griffin menjelaskan bahwa konsumen yang loyal memiliki karakteristik sebagai berikut:

1. Melakukan pembelian produk secara teratur

2. Membeli antar lini produk dan jasa

3. Mereferensikan kepada orang lain.

4. Menunjukkan kekebalan terhadap tarikan dari pesaing. ${ }^{23}$

\section{Metode Penelitian}

Jenis penelitian ini menggunakan penelitian library research atau penelitian pustaka. Penelitian pustaka yaitu suatu penelitian yang dilakukan di ruang perpustakaan untuk menghimpun dan menganalisis data yang bersumber dari perpustakaan baik berupa buku-buku periodikal-periodikal seperti majalahmajalah ilmiah yang diterbitkan secara berkala, kisah-kisah sejarah, dokumendokumen dan materi perpustakaan lainnya yang dapat yang dapat dijadikan sumber rujukan untuk menyusun suatu laporan ilmiah. ${ }^{24}$ Library research ini menggunakan pendekatan kualitatif yaitu pendekatan yang yang merupakan pendekatan yang melakukan penelitian yang berorientasi pada fenomena atau gejala yang bersifat alami. ${ }^{25}$ Bersifat alami disini dimaksudkan peneliti adalah tidak melakukan penelitian di laboratorium.

${ }^{23}$ Jill Griffin, Customer Loyalty : Menumbuhkan Dan Mempertahankan. Pelanggan. (Jakarta Erlangga, 2003), 31.

${ }^{24}$ Abdurrahmat Fathoni, Metodologi Penelitian dan Teknik Penyusunan Skripsi, (Jakarta: PT Rineka Cipta, 2006), 95

${ }^{25}$ Muhammad Ali, Strategi Penelitian Pendidikan. (Bandung: Angkasa, 2009), 159 
Dalam penelitian ini bersifat deskriptif, artinya setiap data yang dikumpulkan berupa kata-kata, gambar dan bukan berupa angka-angka. Semua data yang dikumpulkan berkemungkinan menjadi kunci terhadap apa yang sudah diteliti. Penelitian ini berisi kutipan-kutipan data untuk memberi gambaran penyajian laporan. Dalam penelitian ini di titik beratkan untuk menjawab pertanyaan "mengapa", bagaimana", atau "alasan apa". ${ }^{26}$ Dalam penelitian ini, peneliti hanya memaparkan data yang berupa kata-kata atau uraian yang tertulis. Dengan demikian data yang diperoleh berupa kutipan-kutipan sudah dapat memberikan gambaran penyajian laporan ini. Pertanyaan yang digunakan hanya “apa/apa saja”, dan bagaimana" agar pembahasan ini mudah difahami.

\section{Sumber Data}

Sumber data menurut Arikunto adalah dari mana data dapat diperoleh. Data yang diperoleh peneliti bersumber dari kitab-kitab atau buku-buku, dokumen-dokumen dan literatur-literatur yang terkait lainnya. ${ }^{27}$ Penelitian ini merupakan penelitian kepustakaan ada dua sumber data yang akan dipakaii dalam penelitian ini. Pertama, sumber data primer yakni buku-buku referensi yang menjadi sumber utama dalam penelitian. Kedua, sumber data sekunder adalah sumber referensi pendukung dalam penelitian ini.

\section{Teknik Pengumpulan Data}

Metode pengumpulan data yang digunakan adalah metode dokumentasi. Metode dokumentasi adalah mengumpulkan data dengan melihat atau mencatat suatu laporan yang sudah tersedia. ${ }^{28}$ Data yang sudah tersedia tersebut peneliti ambil dari beberapa buku dan majalah.

Pengumpulan data yang dilakukan dalam penelitian ini adalah:

a. Menggali literatur-literatur seperti kitab-kitab tafsir, majalah, dan artikel yang terkait lainnya.

\footnotetext{
${ }^{26}$ Ahmad Tanzeh, Metode Penelitian Praktis, (Jakarta: PT. bina ilmu, 2004), 42.

${ }^{27}$ Suharsimi Arikunto, Prosedur Penelitian "Suatu Pendekatan Praktek, (Jakarta Rineka Cipta, 2011), 107

${ }^{28}$ Ibid., 130
} 
b. Menganalisis buku bacaan pluralisme agama yang ditawarkan literaturliteratur tersebut.

c. Mengorganisir konsep-konsep tersebut lalu menyusunnya secara sistematis sesuai dengan sistematika penelitian yanga akan dijelaskan dari sistematika pembahasan.

Teknik Analisis Data

Metode yang lebih mengedepankan pada pengungkapan aspek isi (esensi) dari beberapa proposisi yang ada. ${ }^{29}$ Lebih lanjut metode ini merupakan watak dari peninjauan berbagai teori dan analisis.

\section{Hasil Penelitian dan Pembahasan}

A. Menciptakan kepuasan pelanggan melalui service quality

Menciptakan pelayan yang berkualitas diperlukan juga peranan dan para karyawan yang dimana mereka juga sebagai pelaku utama yang secara langsung berhadapan dengan konsumen untuk memberikan pelayanan. Karyawan merupakan bagian integral perusahaan yang mewakili perusahaan dalam berinteraksi dengan konsumen karenanya kinerja karyawan akan menentukan apakah penyedia jasa tersebut mampu memberikan suatu jaminan atau assurance akan tercapainya keinginan konsumen. ${ }^{30}$ Perusahaan jasa berbeda dengan usaha manufaktur. Proses transaksi jasa nyaris sepenuhnya dihantarkan oleh manusia. Bahkan ada beberapa bidang jasa yang memerlukan keterlibatan pelanggan dalam proses transfer jasa. Keberhasilan dalam industri jasa kinerja diukur melalui kualitas hubungan interaksi antara karyawan dengan pelanggan.

Karyawan merupakan aset penting bagi perusahaan jasa oleh karena itu kemampuan elemen ini untuk menciptakan perbedaan yang dapat menciptakan kepuasan dan loyalitas konsumen. kinerja karyawan terutama karyawan lini depan sangat diperlukan untuk menentukan bagaimana proses pertukaran atau penambahan nilai tersebut berlangsung.

\footnotetext{
${ }^{29}$ Muhajir Noeng, Metodologi Penelitian Kualitatif: Telaah Positifistik, Rasionalistik, Realisme Metaphisik, (Yogyakarat: Rake Sarasin, Cet. IV, 2009), 50.

${ }^{30}$ S. Pantja Djati, dan M. Khusaini. Kajian terhadap kepuasan kompensasi,komitmen organisasi, dan prestasi kerja. Jurnal Manajemen dan Kewirausahaan, 5(1), 2003
} 
Ketanggapan, empati, jaminan dan kehandalan karyawan selama proses transfer menjadi stimulus bagi pembentukan persepsi konsumen akan kinerja jasa.

Pada perusahaan yang bergerak di bidang jasa, khususnya jasa perbankan, keunggulan bersaing sering diupayakan dalam bentuk pelayanan yang unggul. ${ }^{31}$ Menurut Wahles yang dikutip oleh Anggoro menyatakan bahwa strategi yang tepat dan akurat dalam kualitas layanan merupakan faktor penting yang mempengaruhi keunggulan bersaing bila direncakan dan diimplementasikan dengan tepat. Dalam jasa bank, kualitas produk yang diukur adalah kualitas layanan. Parasuraman et al mendefinisikan kualitas pelayanan sebagai layanan yang diterima konsumen telah sesuai dengan harapan konsumen akan kualitas. ${ }^{32}$ Dalam hal ini, untuk mengetahui apakah kualitas pelayanan yang diterima konsumen telah sesuai dengan harapan konsumen, didapatkan melalui angket ataupun wawancara mengenai komplain konsumen. Hal pokok yang mendasari kualitas pelayanan adalah indikator-indikatornya yang dapat digunakan untuk mengevaluasi kualitas pelayanan, tanpa memandang jenis layanan. Kualitas jasa dapat didefinisikan sebagai perbedaan antara harapan atau keinginan dengan persepsi konsumen.

Dalam mengukur persepsi konsumen terhadap kualitas jasa dapat dilakukan menggunakan teori service quality (SERVQUAL). Instrumen ini tersusun oleh lima dimensi dan mengukur persepsi konsumen berdasarkan pengalamannya dari jasa yang telah diterimanya apakah sesuai dengan ekspektasinya atau tidak. Berry dan Parasuraman menyatakan bahwa terdapat lima dimensi atau ukuran kualitas jasa atau pelayanan, yaitu: tangible (fisik), reliability (keandalan), responsiveness (cepat tanggap), assurance (kepastian), dan emphaty (empati). ${ }^{33}$

${ }^{31}$ R Agustinus Pribadi Anggoro, dkk. Strategi Membangun Kualitas. Pelayanan Perbankan untuk Menciptakan Kepuasan Nasabah Berorientasi. Loyalitas pada BRI Cabang Blora dan Unit onlinenya. 1994.

${ }^{32}$ Parasuraman et al, Servqual: Multiple Item Scale ..., 26.

${ }^{33}$ Ibid., 26. 
Dalam menciptakan kepuasan nasabah, perusahaan harus dapat meningkatkan nilai nasabah (customer value) maupun keunggulan produknya. Nilai nasabah dapat diciptakan melalui kualitas pelayanan yang diberikan oleh perusahaan kepada para pelanggannya. Semakin baik kualitas pelayanannya, akan semakin tinggi pula nilai pelanggan terhadap perusahaan tersebut. Tingginya kualitas pelayanan juga tidak lepas dari dukungan internal perusahaan, terutama dukungan dari sumber daya manusianya. Bank adalah bentuk perusahaan yang berorientasi pada kepuasan nasabah. Kepuasan ini menyangkut kredibilitas bank dimata nasabah. Kepuasan timbul dari suatu proses yang lama sampai kedua belah pihak saling memberikan timbal balik. Jika kepuasan sudah timbul antara bank dan nasabah, maka usaha untuk membina kerja sama akan lebih mudah sehingga akan memberikan keuntungan bagi kedua belah pihak.

B. Menciptakan loyalitas pelanggan melalui service quality

Seorang konsumen dikatakan setia atau loyal apabila menunjukkan perilaku pembelian secara teratur atau terdapat suatu kondisi dimana mewajibkan pelanggan membeli paling sedikit dua kali dalam selang waktu tertentu. Kondisi seperti ini menempatkan konsumen sebagai pelanggan. ${ }^{34}$ Jika, perusahaan telah mampu menjadikan konsumen menjadi pelanggan perusahaan, maka hal mutlak yang harus dilakukan perusahaan adalah usaha untuk tetap mempertahankan pelanggan agar menjadi pelanggan yang loyal.

Menurut Polyorat telah mengidentifikasi kualitas layanan sebagai penentu loyalitas pelanggan. Menunjukan bahwa semakin tinggi kualitas layanan yang diberikan, semakin besar kemungkinan para pelanggan akan menjadi setia pada perusahaan. Jika pelanggan merasakan hal tersebut dapat dipahami karena layanan yang diberikan perusahaan baik, maka konsumen akan kembali menggunakan produk atau jasa tersebut. ${ }^{35}$

\footnotetext{
${ }^{34}$ Griffin. Customer Loyalty..., 30.

${ }^{35}$ Kawpong Polyorat dan Sophonsiri Suvenus. The Influence of Service. Dimensions Customer.Vol 6. No 2. Journal of Global Business and Technology (2010), 67.
} 
Loyalitas pelanggan sebagai kekuatan hubungan antara sikap relatif individu terhadap suatu kesatuan (merek, jasa, toko, atau pemasok) dan pembelian ulang. Loyalitas pelanggan merupakan suatu sikap yang menggambarkan perilaku aktual dari pelanggan yang tidak ditampakkan atau tidak disadari, tetapi analisis dan gambaran yang benar secara jelas diperlukan untuk mendasari struktur sikap dari pelanggan.

Kualitas pelayanan (Service Quality) yang terdiri atas tangibles, reliability, responsiveness, assurance, dan empathy yang positif berpengaruh langsung dengan indikator loyalitas pelanggan (Customer Loyalty) yaitu mengatakan hal yang positif (say positive things), memberikan rekomendasi kepada orang lain (recommend friend) dan melakukan pembelian terus-menerus (continue purchasing).

Atribut Pembentuk Loyalitas Menurut Griffin ada 4 atribut dari loyalitas, yaitu:

1. Makes regular repeat purchase, melakukan pembelian secara berulang dalam periode tertentu.

2. Purchase across product and service line, pelanggan yang loyal tidak hanya membeli satu macam produk saja melainkan membeli lini produk dan jasa lain pada badan usaha yang sama.

3. Refers other, merekomendasikan pengalaman mengenai produk dan jasa kepada rekan atau pelanggan yang lain agar tidak membeli produk dan jasa dari badan usaha yang lain.

4. Demonstrates an immunity to the pull of the competition, menolak produk lain karena menganggap produk yang dipilihnya adalah yang terbaik. $^{36}$

C. Strategi meningkatkan kepuasan pelanggan (customer satisfaction) melalui kualitas pelayanan (service quality)

Kepuasan merupakan salah satu faktor penting yang mempengaruhi kepuasan hidup, karena sebagian besar waktu manusia dihabiskan di tempat kerja. Kepuasan dapat didefinisikan sebagai suatu perasaan positif tentang pekerjaan seseorang yang merupakan hasil dari sebuah evaluasi

\footnotetext{
${ }^{36}$ Griffin. Customer Loyalty..., 31.
} 
karakteristiknya. Seseorang dengan tingkat kepuasan yang tinggi memiliki perasaan-perasaan positif tentang pekerjaan tersebut, sementara seseorang yang tidak puas memiliki perasaan-perasaan yang negatif tersebut.

Konsumen yang loyal mempunyai kecenderungan yang pasti dalam membeli apa dan dari siapa. Pembelian yang dilakukan bukan pembelian yang bersifat acak, loyalitas juga dapat juga dianggap sebagai suatu kondisi yang berhubungan dengan rentang waktu dalam melakukan pebelian tidak lebih dari dua kali dalam mempertimbangkannya.

Unit keputusan dapat diartikan sebagai suatu keputusan pembelian yang dapat dilakukan oleh lebih dari satu orang. Mereka yang dapat dikategorikan sebagai konsumen yang setia adalah mereka yang sangat puas dengan kualitas produk tertentu sehingga mereka mempunyai antusiasme untuk mmperkenalkanya pada yang mereka kenal, selanjutnya tahap berikutnya ialah konsumen yang loyal tersebut akan memenuhi kesetiaan mereka dengan produk-produk lain buatan produk yang sama pada akhirnya mereka adalah konsumen yang setia kepada produsen tertentu untuk selamanya.

Menurut Oliver yang oleh Ratih Hurriyati (2005:129) loyalitas adalah: Customer loyality is deeply held commitment to rebuy or repatronize a preferred vice consistenly in the future, despite situasional influences and marketing efforts having the potential to cause switching behavior. Dari definisi di atas terlihat bahwa loyalitas pada dasarnya merupakan suatu sikap dari konsumen atau konsumen yang melakukan pembelian berulang untuk produk atau jasa yang sama secara konsisten yang ditawarkan oleh perusahaan atau produsen, dimana komitmen konsumen terhadap produk/jasa tersebut positif dan melalui suatu proses evaluasi.

Kepuasan pelanggan (customer satisfaction) melalui kualitas pelayanan (service quality) dapat direbut dan dipertahankan dengan beberapa pendekatan sebagai berikut :

1. Memperkecil kesenjangan-kesenjangan yang terjadi antara pihak manajemen dengan pelanggan. Riset konsumen untuk menyerap persepsi pelanggan mengenai kualitas pelayanan dapat dilakukan dengan metoda 
customer focus group,mengedarkan angket pelayanan setiap periode tertentu, atau menggunakan pegawai front office untuk mengamati adanya perbedaanpersepsi. Sedangkan penelitian mengenai perilaku pegawai dilakukan dengan mengamati pelaksanaan pelayanan.

2. Perusahaan harus mampu membangun komitmen bersama untuk menciptakan visi dalam perbaikan proses pelayanan. Komitmen bersama dalam hal ini adalah memperbaiki cara berpikir, perilaku, kemampuan, dan pengetahuan dari semua sumberdaya manusia yang ada, baik dari manajemen tingkat atas, menengah, sampai karyawan pelayanan. Sarana penunjang yang digunakan untuk mempertahankan komitmen dengan pelanggan internal diantaranya adalah metoda brainstorming, management by walking around, kotak saran, dan sebagainya.

3. Memberi kesempatan kepada pelanggan untuk menyampaikan keluhan. Sarana yang dapat digunakan antara lain, perusahaan dapat mengadakan hotline bebas pulsa, atau dapat mengadakan ghost shopping, yaitu perusahaan mencari informasi mengenai catatan baik buruknya pembeli potensial ketika membeli produk perusahaan pesaing. Perusahaan dapat juga menerapkan lost customer analysis untuk menghubungi pelanggan yang tidak pernah lagi menggunakan produk perusahaan.

4. Mengembangkan dan menerapkan accountable, proactive, dan partnership marketing sesuai dengan situasi pemasaran. Accountable marketing adalah usaha perusahaan untuk menghubungi pelanggan dalam waktu yang tidak terlalu lama setelah memberikan jasa untuk mengetahui kepuasan dan harapan pelanggan. Proactive marketing adalah usaha perusahaan untuk menghubungi pelanggan dari waktu ke waktu untuk mengetahui perkembangan pelayanan kepada pelanggannya. Partnership marketing adalah perusahaan membangun kedekatan dengan pelanggan, yang bermanfaat untuk meningkatkan citra dan posisi perusahaan di pasar.

Dalam menentukan tingkat kepuasan pelanggan, terdapat lima faktor utama yang harus diperhatikan oleh perusahaan yaitu: 
1. Kualitas Produk: pelanggan akan puas bila hasil evaluasinya menunjukkan bahwa produk yang dinikmati atau digunakan berkualitas.

2. Kualitas Pelayanan : pelanggan akan merasa puas bila mereka mendapatkan pelayanan yang baik atau yang sesuai dengan yang diharapkan.

3. Harga: produk yang mempunyai kualitas yang sama tetapi menetapkan harga yang relatif murah akan memberikan nilai yang lebih tinggi kepada pelanggannya.

4. Personal Factors seperti emosional pelanggan, dimana pelanggan akan merasa bangga dan mendapat keyakinan bahwa orang lain akan kagum terhadapnya bila dia dapat menggunakan produk atau jasa tertentu yang cenderung mempunyai tingkat kepuasan yang lebih tinggi.

5. Situasional Factors, seperti kondisi cuaca yang tidak mendukung, atau pelanggan tidak perlu mengeluarkan biaya tambahan atau tidak perlu membuang waktu lebih untuk mendapatkan suatu produk atau jasa. Sehingga dari faktor-faktor tersebut sangatlah jelas bahwa service quality (kualitas pelayanan) sangat mempengaruhi tingkat kepuasan yang dirasakan oleh para pelanggan. ${ }^{37}$

Pada prinsipnya perlu dilakukan berbagai strategi kepuasan pelanggan yang akan menyebabkan setiap penjual jasa untuk bekerja keras dalam usahanya memperebutkan pelanggan dan memenuhi berbagai harapan yang diinginkan pelanggan terhadap jasa. Harapan pelanggan dibentuk dan didasarkan oleh beberapa faktor, di antaranya pengalaman berbelanja di masa lampau, opini teman dan kerabat, serta informasi dan janji-janji perusahaan dan para pesaing.

Dari pernyataan diatas ada dua faktor yang mempengaruhi kualitas jasa, yaitu expected service dan perceived service. Apabila jasa yang diterima atau dirasakan (perceived service) sesuai dengan yang diharapkan (expcted service), maka kualitas jasa dipersepsikan memuaskan. Jika jasa yang diterima melampaui harapan pelanggan, maka kualitas jasa dipersepsikan sebagai kualitas yang ideal. Sebaliknya jika jasa yang diterima lebih rendah dari pada yang diharapkan, maka kualitas jasa dipersepsikan buruk. Oleh karena itu

${ }^{37}$ Zeithaml, V.A., \& Bitner, M. J., Service Marketing: Integrating Customer Focus Across the Firm. Second Edition. New York: The McGraw-Hill Companies. 1996. 
setiap penyedia jasa harus senantiasa memberikan kualitas jasa yang sesuai atau bahkan melebihi dari harapan pelanggan, sehingga setiap pengguna jasa akan mendapatkan kepuasan yang maksimal atas jasa yang telah meraka rasakan dari perusahaan tersebut.

D. Strategi Pengelolaan Service Quality dalam meningkatkan loyalitas pelanggan

Sebuah perusahaan dapat memenangkan persaingan dengan menyampaikan secara konsisten layanan yang bermutu lebih tinggi dibandingkan para pesaing dan yang lebih tinggi dari pada harapan pelanggan. Harapan-harapan itu dibentuk oleh pengalaman di masa lalu, pembicaraan dari mulut ke mulut, dan iklan perusahaan jasa. Setelah menerima jasa itu, pelanggan membandingkan jasa yang dialami dengan jasa yang diharapkan. Jika jasa yang dialami berada dibawah jasa yang diharapkan, pelanggan tidak berminat lagi terhadap penyedia jasa itu. Jika jasa yang dialami memenuhi atau melebihi harapan,mereka akan menggunakan penyedia jasa itu lagi.

Kualitas pelayanan dapat diukur dengan melihat tingkat kesenjangan antara harapan atau keinginan konsumen dengan persepsi mereka terhadap kinerja produk atau perusahaan yang diterima oleh konsumen yang dapat dijelaskan dalam skala service quality. Pasuraman menyatakan ada lima dimensi yang digunakan oleh pelanggan untuk menilai kualitas pelayanan pada suatu industri yaitu : Kehandalan (reliability) merupakan suatu kemampuan untuk memberikan jasa yang dijanjikan dengan akurat dan terpercaya, dimana kinerja harus sesuai dengan harapan pelanggan yaitu ketepatan waktu, pelayanan yang sama untuk semua pelanggan tanpa ada kesalahan. $^{38}$

Ketanggapan (responsiveness) merupakan suatu kebijakan untuk membantu dan memberikan pelayanan yang cepat kepada pelanggan. Jaminan / kepastian (assurance), yaitu pengetahuan dan keramahan karyawan serta kemampuan melaksanakan tugas secara spontan, yang dapat menjamin kinerja yang baik sehingga menimbulkan kepercayaan dan keyakinan pelanggan.

\footnotetext{
${ }^{38}$ Pasuraman, A., Zethmal, Valerie, Leonard L. Berry, Reassessment of expectations as a
} Comparison Standard in Measuring Service Quality,1994. 
Empati (emphaty), yaitu memberikan perhatian yang bersifat individual atau pribadi kepada pelanggan dan berupaya untuk memahami keinginan konsumen. Berwujud (tangibles), yaitu penampilan dan kemampuan sarana dan prasarana fisik yang dapat diandalkan, serta keadaan lingkungan sekitar sebagai bukti nyata dari pelayanan yang diberikan oleh pemberi jasa.

Loyalitas pelanggan merupakan reaksi atau akibat dari terciptanya kepuasan pelanggan sebagai implementasi dari keberhasilan pelayanan yang berkualitas dalam memenuhi harapan pelanggan. Pelanggan yang loyal adalah mereka yang antusiasme terhadap merek atau prouk yang digunakannya. Pelanggan yang loyal kepada keputusan pembeliannya tidak lagi mempertimbangkan faktor-faktor yang berpengauh dalam penentuan pilihan seperti tingkat harga, jarak, kualitas, dan atribut lainnya, karena telah tertanam dalam dirinya bahwa produk atau jasa yang dibeli sesuai dengan harapn dan mampu memenuhi kebutuhan.

Pelanggan yang loyal atau setia adalah sesorang yang melakukan pembelian ulang dari perusahaan yang sama, memberitahukan kekonsumen potensial yang lain dari mulut ke mulut. Loyalitas adalah suatu perilaku pembelian pengulangan yang menjadi kebiasaan, yang mana telah ada keterkaitan dan keterlibatan tinggi pada pilihannya tehadap obyek tetentu, dan bercirikan dengan ketiadaan pencarian informasi eksternal dan evaluasi alternative. ${ }^{39}$

Pelanggan yang loyal sangat besar artinya bagi perusahaan, begitu juga pelanggan layanan internet Flash Unlimited yang loyal sangat penting bagi perusahaan. Karena pelanggan yang loyal berarti kelangsungan hidup perusahaan, dan tentu saja meningkatkan profitabilitas perusahaan. Pemahaman loyalitas pelanggan sebenarnya tidak hanya dilihat dari transaksinya saja atau pembelian berulang.

Ada beberapa ciri suatu pelanggan dianggap loyal:

1. Pelanggan yang melakukan pembelian ulang secara teratur.

2. Pelanggan yang membeli produk yang lain di tempat yang sama.

3. Pelanggan yang mereferensikan kepada orang lain.

${ }^{39}$ Engel. et.al. Perilaku Membeli..., 98. 
4. Pelanggan yang tidak dapat dipengaruhi pesaing untuk pindah.

Loyalitas konsumen merupakan manifestasi dan kelanjutan dari kepuasan konsumen dalam menggunakan fasilitas maupun jasa pelayanan yang diberikan oleh perusahaan, serta untuk tetap menjadi konsumen dari perusahaan tersebut. Di dalam pasar yang persaingannya sangat ketat, banyak alternative merek, harga bervariasi, dan banyak produk pengganti, maka loyalitas merek pada umumnya cenderung menurun. Oleh karenanya perusahaan yang ingin tetap bertahan perlu mengembangkan strategi pemasaran, dengan harapan konsumen tetap memiliki loyalitas terhadap produk dari perusahaan tersebut. Hal ini sangat penting, karena menurut Reichard dan Sasser dalam hasil penelitiannya menunjukkan bahwa setiap peningkatan $5 \%$ pada kesetiaan pelanggan dapat meningkatkan keuntungan $25 \%$ - 85\% dengan demikian dapat dikatakan bahwa keberhasilan suatu perusahaan ditentukan oleh loyalitas pelanggan. ${ }^{40}$ Loyalitas dapat dicapai melalui dua tahap:

1. Peruasahaan harus mempunyai kemampuan dalam memberikan kepuasan kepada konsumennya agar konsumen mendapatkan suatu pengalaman positif.

2. Perusahaan harus mempunyai cara untuk mempertahankan hubungan yang lebih jauh dengan konsumennya dengan menggunakan kesetiaan yang dipaksa (Forced Loyalty) supaya konsumen ingin melakukan pembelian ulang. ${ }^{41}$

Dalam jangka panjang, loyalitas pelanggan menjadi tujuan bagi perencanaan pasar stratejik. Selain itu juga dijadikan dasar untuk pengembangan keuntungan kompetitif yang berkelanjutan (Dick dan Basu Swastha, 1994), yaitu keunggulan yang dapat direalisasikan melalui upayaupaya pemasaran. Dalam lingkungan persaingan global yang semakin ketat dengan masuknya produk-produk inovatif ke pasaran di satu sisi, dan kondisi pasar yang jenuh untuk produk-produk tertentu di sisi lain, tugas mengelola loyalitas pelanggan menjadi tantangan manajerial yang tidak ringan.

\footnotetext{
${ }^{40}$ Reichheld dan Sasser. Zero Defections: Quality Comes To Services. Harvard Business Review, 68(5), 1990. p.105-11.

${ }^{41}$ Kotler dan Armstrong, Prinsip-prinsip Pemasaran..., 102
} 
Sedangkan menurut (Jacoby dan Olson) mengutarakan pengertian loyalitas pelanggan menekankan pada runtutan pembelian, proporsi pembelian, atau dapat juga probabilitas pembelian. ${ }^{42}$ Dalam lingkungan bisnis dimana persaingan berlangsung sangat keat sepeti saat ini, upaya memenangkan persaingan tidak hanya didasarkan pada mutu produk atau jasa yang tinggi, harga jual bersaing, tetapi juga upaya terpadu untuk memberikan kepuasan pada pelanggan dan memenuhi kebutuhan lebih baik sesuai dengan yang diharapkan pelanggan. Pelanggan yang setia bisa menjdi partner dalam mngembangkan produk baru. Mereka mempertahankan dan membela pelayanan perusahaan yang ada.

\section{Kesimpulan}

Mempertahankan pelanggan telah dianggap oleh banyak penyedia jasa sebagai variabel penting dalam memenangkan persaingan. Dengan terciptanya loyalitas pelanggan akan mengarahkan pada profitabilitas yang lebih besar dan pertumbuhan. Penelitian ini membuktikan bahwa loyalitas akan tercipta dengan mempertahankan citra melalui penciptaan persepsi yang baik akan atribut-atribut produk dan menerapkan program sercive recovery dengan jalan meminta maaf bila melakukan kesalahan, mengambil tindakan dengan segera, menunjukkan penyesalan, memberikan garansi dan melakukan tindak lanjut. Selain itu menciptakan kepuasan pelanggan merupakan variabel yang tidak dapat ditinggalkan dalam rangka menciptakan alasan bagi pelanggan untuk tetap bersedia menjalin hubungan jangka panjang dengan perusahaan.

Perusahaan harus melakukan pengelolaan service quality untuk dapat merebut dan mempertahankan kepuasan pelanggan (customer satisfaction). Kualitas pelayanan memiliki esensi penting bagi strategi perusahaan untuk mempertahankan diri dan mencapai sukses dalam menghadapi persaingan. Karena kualitas pelayanan yang lebih tinggi menghasilkan kepuasan pelanggan yang lebih tinggi. Apabila jasa yang diterima atau dirasakan (perceived service) sesuai

\footnotetext{
${ }^{42}$ Jacob Jacoby and Jerry C. Olson, AN Attitudinal Model of Brand Loyalty: Conseptual Underpinnings and Instrumention Research, Purdue Papers in Consumer Psychology 159, Purdue University 1970
} 
dengan yang diharapkan (expcted service), maka kualitas jasa dipersepsikan memuaskan. Jika jasa yang diterima melampaui harapan pelanggan, maka kualitas jasa dipersepsikan sebagai kualitas yang ideal. Sebaliknya jika jasa yang diterima lebih rendah dari pada yang diharapkan, maka kualitas jasa dipersepsikan buruk. Lebih jauh lagi, perusahaan juga harus membuat pelanggan bukan hanya sekedar merasakan kepuasan (satisfaction). Karena pelanggan yang puas masih terbuka kemungkinan untuk beralih ke produk perusahaan lain atau produk pesaing. Sehingga perusahaan harus dapat menciptakan perasaan dan pengalaman yang menyenangkan bagi konsumen (customer delight)

\section{Saran}

Hendaknya suatu perusahaan senantiasa menciptakan kepuasan dan loyalitas pelanggan dengan melalui kualitas pelayanan. Kualitas pelayanan adalah tingkat dimana persepsi kualitas pelayanan sesuai dengan harapan pelanggan. Untuk dapat meningkatkan kepuasan pelanggan dan loyalitas, maka perusahaan harus lebih meningkatkan kualitas pelayanan. Untuk dapat meningkatkan kualitas pelayanan, maka pihak perusahaan harus dapat meningkatkan fasilitas untuk pelanggan. 


\section{Daftar Pustaka}

Agustinus, R. Pribadi Anggoro, dkk. Strategi Membangun Kualitas. Pelayanan Perbankan untuk Menciptakan Kepuasan Nasabah Berorientasi. Loyalitas pada BRI Cabang Blora dan Unit onlinenya. 1994.

Ali, Muhammad. Strategi Penelitian Pendidikan. Bandung: Angkasa, 2009.

Arikunto, Suharsimi. Prosedur Penelitian "Suatu Pendekatan Praktek, Jakarta Rineka Cipta, 2011.

Djati, S. Pantja dan M. Khusaini. Kajian terhadap Kepuasan Kompensasi, Komitmen Organisasi, dan Prestasi Kerja. Jurnal Manajemen dan Kewirausahaan, 5(1), 2003

Fathoni, Abdurrahmat. Metodologi Penelitian dan Teknik Penyusunan Skripsi, Jakarta: PT Rineka Cipta, 2006.

Giese \& Cote Academy of Marketing Science Review. Defining Consumer Satisfaction Volume 2000 No. 1 . (2000). Available: http://www.amsreview.org/articles/giese01-2000.pdf

Griffin, Jill. Customer Loyalty: Menumbuhkan Dan Mempertahankan Pelanggan. Jakarta: Erlangga, 2003.

Hadi, Handito. Intisari, Jangan Sekedar Service, Jakarta: Gramedia, 2003.

Ibrahim. Prinsip-Prinsip Total Quality Service, Yogyakarta: Andi, 1997.

Jacob Jacoby and Jerry C. Olson, AN Attitudinal Model of Brand Loyalty: Conseptual Underpinnings and Instrumention Research, Purdue Papers in Consumer Psychology 159, Purdue_University 1970

James F., Engel. Roger D. Blackwell, Paul .W Miniad. Perilaku Membeli, Jakarta: Binarupa Aksara, 1993.

James, Barnes G. Secrets of Customer Relation ship Management (Rahasia. Manajemen Hubungan Pelanggan). Yogyakarta: Andi, 2000.

Jurnal Manajemen \& Kewirausahaan Vol. 7 tahun 2003. Surabaya: UKP

Kesetiaan Merek (Studi Kasus Restoran The Prime Steak \& Ribs Surabaya)"

Kotler, Philip dan Kevin Lane Keller. Manajemen Pemasaran. diterj. Bob Sabran. Jakarta: Erlangga. 2008.

Kotler, Philip dan Gary Armstrong, Prinsip-prinsip Pemasaran, Jilid 1, Jakarta: Erlangga, 2008.

Lukman, Sampara. Manajemen Kualitas Pelayanan, Jakarta: STIA LAN. 2000.

Lupiyoadi, R. Manajemen Pemasaran Jasa Teori dan Praktik. Jakarta: Salemba Empat, 2006.

Noeng, Muhajir. Metodologi Penelitian Kualitatif: Telaah Positifistik, Rasionalistik, Realisme Metaphisik, Yogyakarat: Rake Sarasin, Cet. IV, 2009.

Oliver, Richard L. dan Jhon E. Swan, Consumer Perceptions of Interpersonal Equity and Satisfaction in Transaction: a Field Survey Approach, Journal Marketing, 1993.

Parasuraman, A. Valerie Zeithaml, and L.Berry. Servqual: Multiple Item Scale for Measuring Consumer Perceptions of Service Quality, Journal of Retailing, 64 (15), 1988.

Pasuraman, A., Zethmal, Valerie, Leonard L. Berry, Reassessment of expectations as a Comparison Standard in Measuring Service Quality,1994. 
Polyorat, Kawpong dan Sophonsiri Suvenus. The Influence of Service. Dimensions Customer.Vol 6. No 2. Journal of Global Business and Technology (2010)

Reichheld dan Sasser. Zero Defections: Quality Comes To Services. Harvard Business Review, 68(5), 1990. p.105-11.

Samuel, Hatane dan Foedjiawati. "Pengaruh Kepuasan Konsumen Terhadap

Surabaya. 2005.

Tanzeh, Ahmad. Metode Penelitian Praktis, Jakarta: PT. bina ilmu, 2004.

Tjiptono, Fandy dan Chandra Gregorius. Service Quality and Satisfaction, Yogyakarta: Andi Offset, 2002.

Tjiptono, Fandy. Manajemen Jasa. Yogyakarta: Andi Offset. 2011.

Triguno. Budaya Kerja, Jakarta: Golden Terayon Press, 1997.

Zeithaml, V.A., \& Bitner, M. J., Service Marketing: Integrating Customer Focus Across the Firm. Second Edition. New York: The McGraw-Hill Companies. 1996. 